\title{
Pembuatan Aplikasi Monitoring Karantina Mandiri Orang dalam Pengawasan (ODP) COVID-19 di Kota Depok
}

\author{
Risna Sari, Mera Kartika Delima Yanti, Dewi Yanti Liliana, Iklima Ermis Ismail \\ Departemen Teknik Informatika, Jurusan Teknik Informatika dan Komputer, Politeknik Negeri Jakarta \\ Jl. Prof. DR. G.A. Siwabessy, Depok, 16424, Indonesia
}

\begin{abstract}
ARTICLE INFO
Received: 2020-11-30

Revised: 2021-01-27

Accepted: 2021-03-11

Keywords:

COVID-19, Monitoring application, People under surveillance, Self-quarantine

\section{ABSTRACT}

The COVID-19 pandemic that has hit all countries in the world is a sudden humanitarian disaster. This virus is highly contagious, so it is necessary to make direct contact to prevent widespread transmission. Meanwhile, for people who have had contact with people with COVID-19, it is necessary to carry out tracing and activity activities so as not to cause more people to be exposed to COVID-19. Therefore, supporting infrastructure is needed in the form of web and mobile-based applications to monitor self-quarantine for COVID-19 People Under Supervision (ODP). The Informatics Engineering Study Program, Department of Informatics and Computer Engineering, Jakarta State Polytechnic developed a web-based and mobile-based software application made for the Depok Jaya Community Health Center to support ODP COVID-19. ODP can report complaints and grievances through the mobile application, while the Depok Jaya Community Health Center conducts monitoring through a web-based application. By using this application, it is hoped that it can break the chain of spreading COVID-19 in Depok City, especially in Depok Jaya District.
\end{abstract}

(C)2021 Published by University of Merdeka Malang. This is an open access article distributed under the CC BY-SA 4.0 license (https://creativecommons.org/licenses/by-sa/4.0/)

How to cite: Sari, R., \& Yanti, M. K. D., Liliana, D. Y., \& Ismail, I. E. (2021). Pembuatan Aplikasi Monitoring Karantina Mandiri Orang dalam Pengawasan (ODP) COVID-19 di Kota Depok. Abdimas: Jurnal Pengabdian Masyarakat Universitas Merdeka Malang, 6(2), 143-152. https://doi.org/10.26905/abdimas.v6i2.5090

\section{PENDAHULUAN}

Pemerintah Kota Depok telah mencanangkan program unggulan salah salah satunya yaitu Smart Healthy City. Bapedda Kota Depok sudah menyusun beberapa program diantaranya penyusunan sistem kesehatan daerah, peningkatkan kualitas dan kuantitas pelayanan kesehatan tingkat pertama, penyelenggaraan database berbasis IT. Semua program yang dibuat untuk menunjang program utama kota Depok menjadi cyber city, yaitu kota yang segala aktivitasnya berbasis teknologi informasi dan komunikasi. Program Studi DIV (PS DIV) Teknik Informatika, Jurusan Teknik Informatika dan Komputer (JTIK), Politeknik Negeri Jakarta (PNJ) yang terletak di Kota Depok harus turut mendukung program 
ABDIMAS: Jurnal Pengabdian Masyarakat Universitas Merdeka Malang

Volume 6, No 2, May 2021: 143-152

tersebut demi kemajuan Kota Depok. Salah satu upaya yang dapat dilakukan oleh PS DIV Teknik Informatika adalah melaksanakan kegiatan pengabdian kepada masyarakat untuk mentransfer IPTEK, khususnya di bidang teknologi informasi dengan mengembangkan sistem terkomputerisasi yang mendukung program pemerintah di segala jenjang.

Kota Depok terdiri atas 11 Kecamatan dan 63 Kelurahan, yang tersebar pada wilayah seluas 200,29 $\mathrm{km}^{2}$. Salah satunya Kelurahan Depok Jaya yang berada di wilayah Kecamatan Tapos memiliki program dalam mendukung Kota Depok menjadi cyber city. Dalam hal ini berkaitan pada masalah kesehatan masyarakat yang terjadi adalah system kesehatan daerah khususnya penyelenggaraan database berbasis IT.

Hari-hari ini, hampir seluruh ruang pemberitaan media diisi dengan topik seputar Pandemi Corona Virus Disease 2019 (COVID-19) atau awam disebut Corona. Sejak kasus pertama virus ini ditemukan pada November 2019 silam, jumlah kasus terus mengalami eskalasi yang signifikan. World Health Organization (WHO) merilis data, sampai dengan tanggal 13 April 2020 pukul $07.00 \mathrm{GMT}+7$, tercatat 1.776.867 kasus COVID-19, termasuk diantaranya 111.828 angka kematian. Di Indonesia, Gugus Tugas Percepatan Penanganan COVID-19 mencatat bahwa sampai dengan tanggal 22 April 2020 pukul 18.00 WIB terdapat 7.418 dinyatakan positif COVID-19 dimana 635 diantaranya meninggal dunia dan 913 dinyatakan sembuh. Pemerintah Indonesia telah menetapkan COVID-19 sebagai jenis penyakit yang menimbulkan kedaruratan kesehatan masyarakat (Pemerintah RI, 2020).

Kondisi ini menyebabkan pemerintah memperlakukan pembedaan pada kondisi pasien di masyarakat yakni Orang Dalam Pengawasan (ODP), Orang Tanpa Gejala (OTG) dan Pasien Dalam Pengawasan (PDP). Pasien yang masuk kategori dari ODP tersebut akan diberitahu oleh petugas kesehatan terkait, dan umumnya diinstruksikan untuk menjalani karantina mandiri selama 14 hari. Selama karantina tersebut, kondisi pasien harus dipantau secara terus menerus oleh tenaga kesehatan. Oleh sebab itu, tenaga kesehatan puskesmas bertugas untuk tetap melakukan monitoring terhadap proses ini. Selama ini proses yang dilakukan oleh petugas puskesmas adalah dengan melakukan pencatatan data monitoring secara manual dari jawaban pasien dengan menggunakan media komunikasi SMS, WhatsApp, atau telepon secara langsung. Pencatatan laporan monitoring secara manual tentu saja akan sangat merepotkan dan tidak bersifat up-to-date (Pemerintah Kota Depok; Republika, 2020).

PS DIV Teknik Informatika PNJ melalui pogram Pengabdian Kepada Masyarakat (PKM) yang bekerjasama dengan petugas puskesmas dari Puskesmas Depok Jaya membuat dan mengimplementasikan aplikasi monitoring karantina mandiri pasien ODP COVID-19. Aplikasi tersebut dibuat berbasis mobile yang bersifat responsif dan user friendly. Harapannya agar aplikasi ini dapat mudah digunakan bagi pasien ODP khususnya pasien ODP lansia. Aplikasi ini akan menjadi solusi untuk petugas puskesmas dalam melakukan pendataan dan memonitor pasien ODP sehingga akan mempermudah pelaporan data pasien. Selain itu, apabila terdapat gejala-gejala COVID-19 pada pasien tersebut dapat segera ditindaklanjuti sehingga pasien lekas mendapatkan perawatan dari RS rujukan.

Mitra kegiatan adalah Puskesmas Depok Jaya Kota Depok, saat ini dalam melaksanakan pencatatan kegiatan pemantauan pasien ODP masih dilakukan secara manual. Hal ini mengakibatkan proses 
pencatatan dan pelaporan data pasien ODP menjadi lambat. Hal ini jelas sangat berbahaya apalagi kondisi di Kota Depok sudah masuk dalam zona merah. Gambar 1 menunjukkan lokasi objek PKM yaitu Puskesmas Depok Jaya.

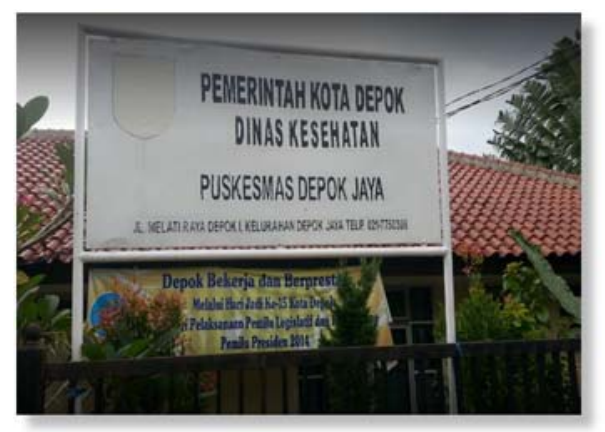

Gambar 1. Puskesmas Depok Jaya

Harapannya, pasien ODP dapat melakukan input mengenai data kondisi tubuh secara rutin melalui aplikasi yang mudah diakses dan diimplementasikan. Dengan teknologi mobile dan jaringan internet akan memudahkan petugas puskesmas untuk memantau kondisi pasien secara real-time. Selain itu, pasien dapat berkonsultasi langsung dengan petugas puskesmas seandainya mengalami gejala-gejala COVID-19 atau gejala sakit lainya. Pemantauan status pasien ODP dilakukan oleh petugas puskesmas. Implementasi dari aplikasi ini dapat dimanfaatkan juga di puskesmas lain untuk pemantauan pasien ODP. Melalui alternatif solusi yang ditawarkan, permasalahan pandemik COVID-19 khususnya di Kota Depok dapat diminimalisir dan dapat mempercepat penanganan pasien positif COVID-19 agar dapat disembuhkan.

Dikutip dari situs Detik.com, jumlah pengguna teknologi internet dan smartphone di Indonesia tercatat sebesar 175,4 juta pada tahun 2020. Pemanfaatan teknologi internet dan smartphone pada bidang kesehatan telah banyak dilakukan, mulai dari kegunaan untuk sistem informasi kesehatan dan rumah sakit, monitoring data kesehatan, hingga menggabungkan teknologi Internet of Things (IoT) berupa alat (wearable) yang dipasang pada pasien maupun smartphone pasien dan data kesehatan pasien dapat langsung tersimpan pada sistem.

Penelitian yang dilakukan oleh Patel \& Kher (2016) menggunakan aplikasi Android untuk memonitor kesehatan mulai dari suhu tubuh, saturasi oksigen darah, detak jantung, kadar gula darah, Electrocardiogram (ECG), dan Electroencephalogram (EGG). Teknologi Android juga dimanfaatkan untuk memonitor pasien penyakit jantung dilengkapi dengan sensor suhu tubuh dan detak jantung serta fitur Geographic Positioning System (GPS) untuk memudahkan tracking lokasi pasien, sehingga dalam kondisi darurat dapat segera diambil tindakan dari lokasi kesehatan terdekat (Gogate et al., 2017). Hal yang sama juga dilakukan oleh Kenganal \& Rengaprabhu (2016) dengan memanfaatkan Android mobile untuk memonitor dan menyimpan data kesehatan pasien penyakit jantung secara real-time, jika data yang diperoleh dari pasien melewati batas standar kondisi normal, maka akan muncul notifikasi secara otomatis pada aplikasi Android dokter. 
ABDIMAS: Jurnal Pengabdian Masyarakat Universitas Merdeka Malang

Volume 6, No 2, May 2021: 143-152

\section{METODE}

Metode penelitian melibatkan tahapan pelaksanaan PKM untuk menemukan solusi atas permasalahan spesifik yang dihadapi oleh mitra. Pelaksanaan solusi tersebut menggunakan etodologi pengembangan sistem Waterfall, yang dimulai dengan perencanaan, analisis, desain, coding, testing, implementasi, dan monitoring (Pressman, 2015). Penggunaan metode Waterfall dipilih karena memfokuskan pada kebutuhan mitra, bukan hanya pada hadirnya aplikasi, mengacu pada Dima \& Maassen (2018) yang membahas mengenai perbandingan antara metodologi Agile dan Waterfall, dimana Agile mengedepankan pada hadirnya aplikasi yang dapat fleksibel dengan perubahan kebutuhan dan feedback dari pengguna, sedangkan Waterfall mengedepankan fiksasi kebutuhan dari klien dari tahap awal pengembangan aplikasi.

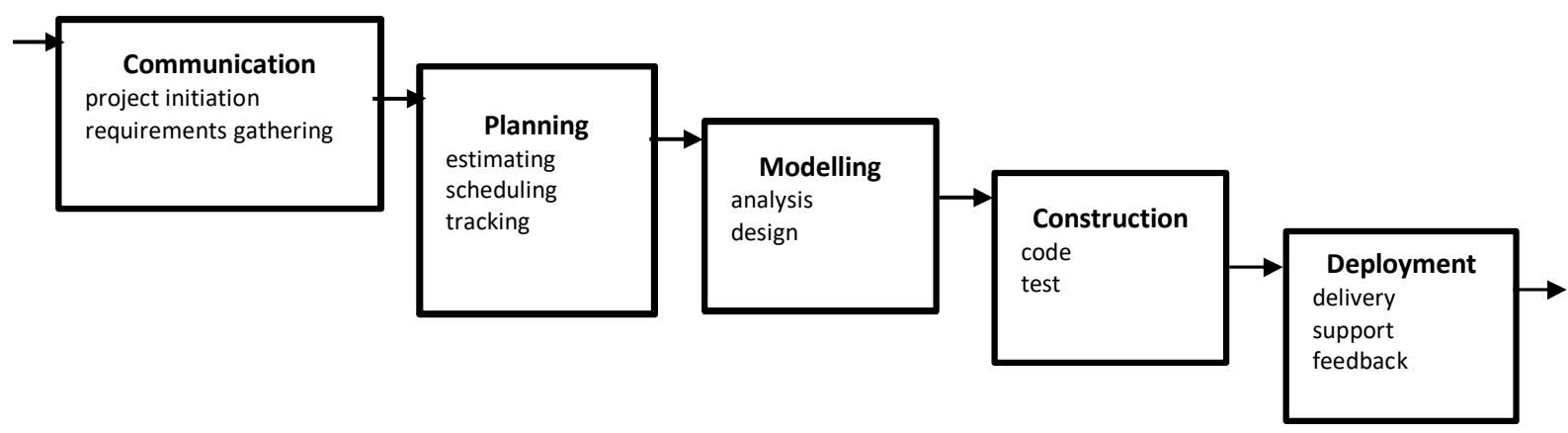

Gambar 2. Tahap metode Waterfall (Pressman, 2015)

Tahap komunikasi dimulai dengan melakukan komunikasi dengan mitra untuk menggali permasalahan prioritas kebutuhan dari mitra. Pada tahap ini dilakukan komunikasi oleh Ketua PS DIV TI dengan perwakilan tenaga kesehatan Puskesmas Depok Jaya melalui chat WhatsApp dikarenakan keterbatasan kondisi untuk bertemu secara langsung. Dari hasil diskusi melalui WhatsApp maka diperoleh kesimpulan mengenai prioritas kebutuhan dari Puskesmas Depok Jaya adalah aplikasi untuk memonitoring kondisi ODP yang dikarantina secara mandiri setiap hari, seperti melaporkan perkembangan suhu, makanan yang dikonsumsi, dan lain-lain. Pada tahap ini diperoleh juga deskripsi alur proses pengecekan gejala yang dilakukan secara manual oleh petugas kesehatan Puskesmas Depok Jaya saat pasien datang langsung ke puskesmas.

Tahap perencanaan merupakan tahapan awal yang digunakan untuk mengetahui kebutuhan pengguna dengan mengspesifikasikan permasalahan prioritas dari mitra. Pada tahap ini dilakukan analisa lebih lanjut mengenai kesesuaian kebutuhan mitra dengan kebutuhan fitur pada aplikasi yang akan dikembangkan. Selanjutnya, melakukan analisis yang didasari dari prosedur pelaksanaan kegiatan sesuai dengan tatanan yang sudah ada, guna membuat aplikasi berbasis mobile monitoring karantina mandiri Orang Dalam Pengawasan (ODP) COVID-19. Platform aplikasi berbasis mobile selain Android, terdapat juga iOS (Masi et al., 2012). Aplikasi ini dikembangkan terbatas pada versi Android, karena sebagian besar pengguna aplikasi mobile di Indonesia sebesar $91,03 \%$ dan iOS sebesar $8,71 \%$.

Tahapan desain, koding, dan testing dilakukan oleh tim mobile developer dari PS DIV Teknik Informatika PNJ. Implementasi sistem dilakukan dengan terlebih dahulu menginisiasi pelaksanaan 
monitoring karantina mandiri pasien ODP oleh pasien langsung dan petugas puskesmas di wilayah mitra. Selain itu, penetapan pengelola/petugas/admin dari pihak mitra juga dilakukan. Tahap implementasi juga dilakukan kegiatan pelatihan instalasi dan penggunaan aplikasi oleh pasien yang dimonitor oleh petugas puskesmas. Langkah akhir dari program ini adalah dengan melakukan monitoring, sebagai bentuk pendampingan penerapan sistem ini.

Metode pendekatan terhadap mitra adalah dengan melakukan kajian bersama tentang visi dan misi pemerintah Kota Depok. Visi dan misi tersebut diimplementasikan dalam bentuk program prioritas dari pemerintah Kota Depok, yang salah satunya adalah program Smart Healthy City dan Cyber City. Kedua, tagline ini merupakan program utama pemerintah Kota Depok, sehingga selaras dengan permasalahan inti yang dijumpai mitra yakni pengelolaan data kesehatan di lingkungannya. Kemudian diselaraskan dengan penawaran sistem dari pihak PS DIV Teknik Informatika PNJ, maka disepakati dilakukan pembuatan aplikasi monitoring karantina mandiri pasien ODP COVID-19 berbasis mobile untuk menangani masalah kesehatan khususnya wabah pandemik COVID-19. Gambar 3 menunjukkan desain aplikasi monitoring karantina mandiri pasien ODP dengan beberapa fitur yang disesuaikan kebutuhan mitra.

Aplikasi ini terdiri dari dua grup pengguna yaitu petugas puskes dan ODP. Aplikasi digunakan dimulai oleh petugas puskes login sehingga dapat membuka dashboard. Dashboard berisi menu input data ODP, melihat laporan ODP, dan membuat kesimpulan hasil monitoring ODP. Aplikasi bisa digunakan oleh ODP apabila petugas puskesmas sudah memasukan data melalui halaman petugas puskesmas. Selanjutnya ODP atau kepala keluarga dapat login ke aplikasi dan mengisi laporan harian ODP dan mengirimkan laporan ke puskesmas melalui aplikasi. ODP juga dapat melakukan update profil untuk memperbaharui kesalahan data.

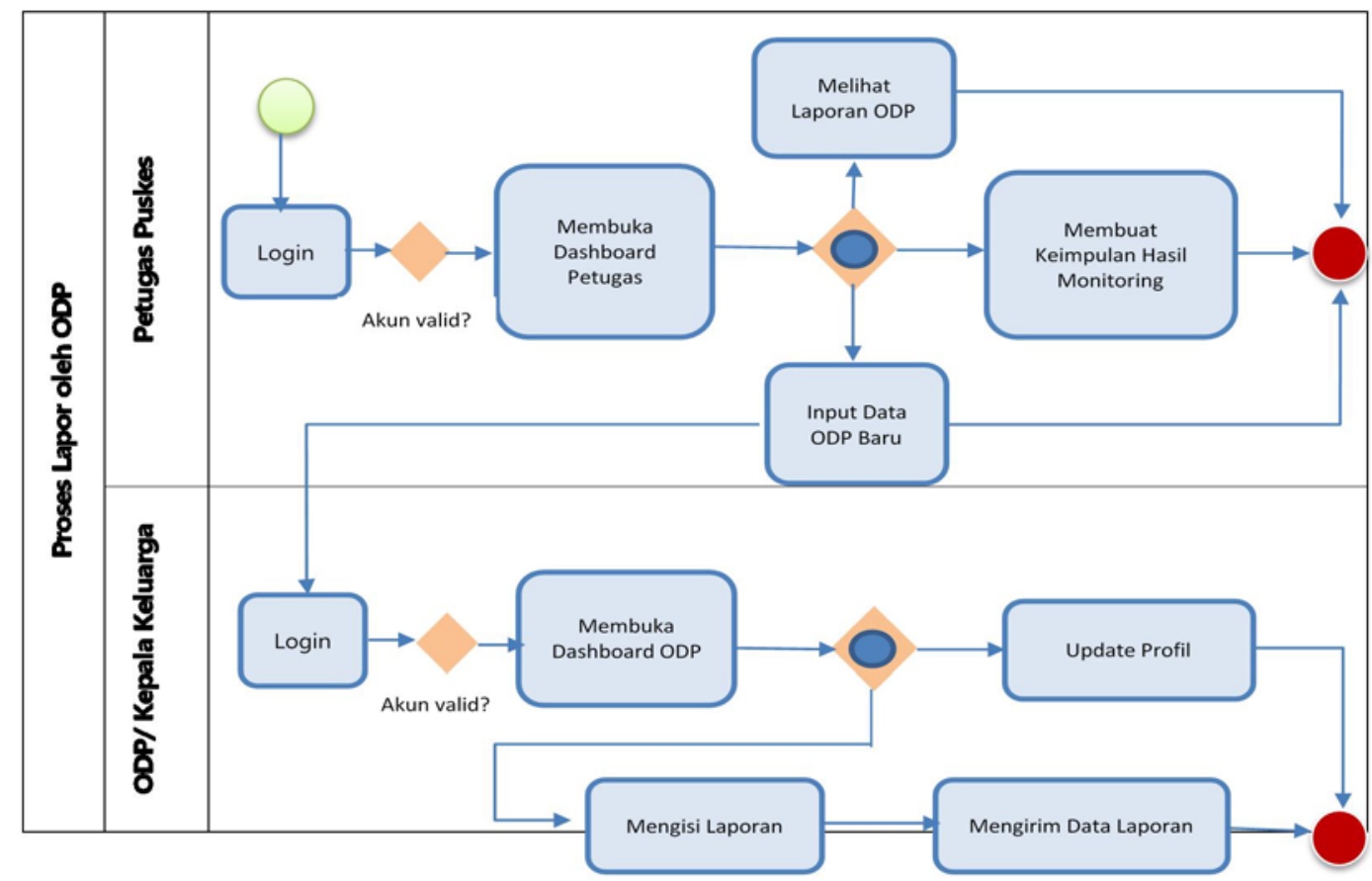

Gambar 3. Diagram alur aplikasi 
ABDIMAS: Jurnal Pengabdian Masyarakat Universitas Merdeka Malang

Volume 6, No 2, May 2021: 143-152

\section{HASIL DAN PEMBAHASAN}

Kegiatan IPTEK bagi Masyarakat (IbM) dalam bentuk pembuatan Aplikasi Monitoring Karantina Mandiri Orang Dalam Pengawasan (ODP) COVID-19 berbasis mobile sangat penting untuk dilakukan karena memperhatikan nilai manfaatnya yang besar, baik secara langsung maupun tidak langsung. Adapun target penerapannya adalah: (1) Aplikasi diberikan kepada petugas puskesmas untuk dimanfaatkan oleh pasien ODP sewaktu melaksanakan karantina mandiri. Kondisi tubuh dan pertanyaanpertanyaan yang berkaitan dengan monitoring wabah COVID-19 ditanyakan secara rutin dan kontinu selama 14 hari karantina; (2) Sistem ini akan mempermudah pemantauan pasien ODP secara real time dan mempermudah petugas puskesmas dalam membuat pelaporan data pasien secara terus-menerus dan secara kontinu.

Luaran yang dihasilkan dari kegiatan pengabdian kepada masyarakat ini adalah aplikasi monitoring karantina mandiri pasien ODP COVID-19 berbasis mobile yang dapat dibuka pada browser smartphone atau diunduh di Play Store. Aplikasi ini dikemas pada handphone yang dilengkapi panduan penggunaan serta slide presentasi pelatihan instalasi dan cara penggunaan aplikasi.

Penyerahan aplikasi diberikan langsung oleh ketua PS DIV Teknik Informatika PNJ yang diterima langsung oleh Kepala Puskesmas Depok Jaya. Dokumentasi serah terima ditampilkan pada Gambar 4. Setelah penyerahan aplikasi, tim PNJ juga tetap membantu memberikan dukungan teknis dan pemeliharaan (Technical Support and Maintenance) aplikasi monitoring ODP COVID-19.

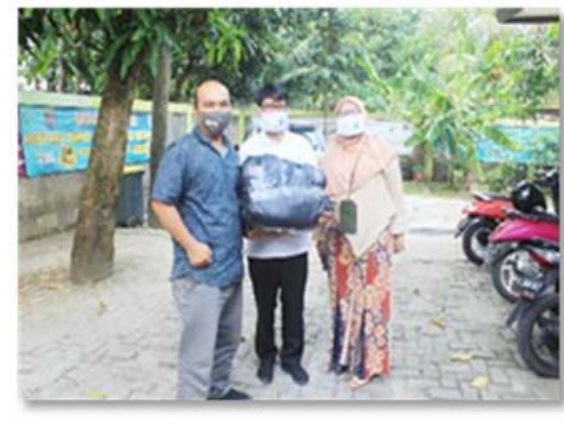

(a)

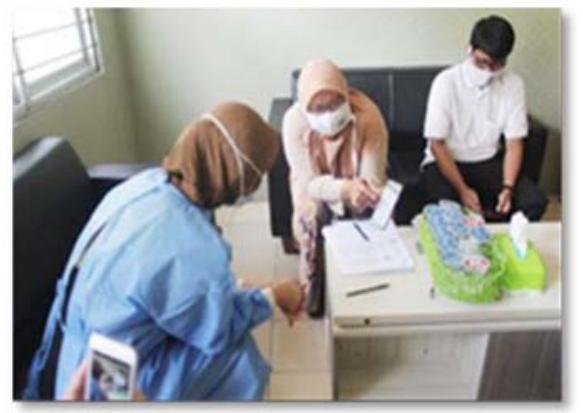

(b)

Gambar 4. (a) Dokumentasi serah terima alat dan aplikasi tim dosen PNJ, (b) Pengarahan penggunaan aplikasi oleh tim dosen PNJ kepada Kepala Puskesmas Depok Jaya

Tampilan aplikasi monitoring ODP COVID-19 versi web dan mobile ditunjukkan pada Gambar 5 dan 6 secara berurutan. Pada Gambar 5, saat petugas puskesmas sebagai admin aplikasi berhasil login, maka aplikasi akan menampilkan halaman dashboard admin, yang berisi ringkasan dan grafik mengenai angka suspek, kasus probable, kasus konfirmasi, dan kontak erat. Petugas puskesmas dapat memantau status pasien ODP menjadi sembuh, masih sakit atau meninggal dunia yang diwakili dengan warna hijau, kuning, dan merah secara berurut. Status ini ditentukan berdasarkan data-data yang diperoleh dari inputan data oleh petugas puskesmas dan juga dari inputan oleh pasien melalui aplikasi mobile dan Android yang terdapat pada Gambar 6.

Halaman dashboard petugas puskesmas terdapat 9 menu utama, yaitu Dashboard, Profile Pasien, Data Test, Riwayat Perawatan, Data Epidemologi, Laporan Harian, Cari dan Cetak Laporan, Akun dan Logout. Keseluruhan menu utama dibuat sesuai dengan hasil analisis requirement/kebutuhan 
dengan pihak puskesmas. Aplikasi Android dibuat dengan tiga privileges/peran, yaitu penanggung jawab (kepala keluarga), pasien (ODP) dan petugas puskesmas. Penanggung jawab dan pasien dapat melaporkan data perkembangan kondisi harian ODP jika sudah mendapatkan akun login dan password dari petugas puskesmas.

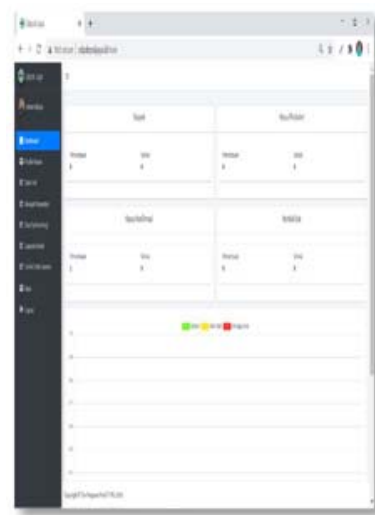

(a)

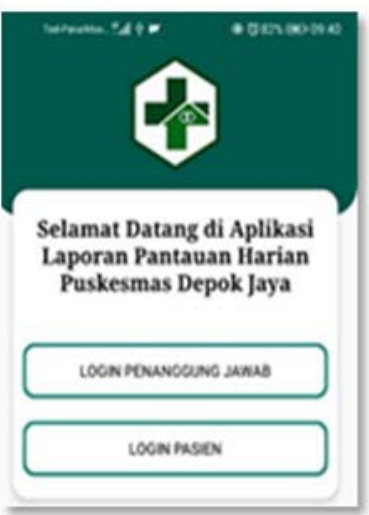

(b)

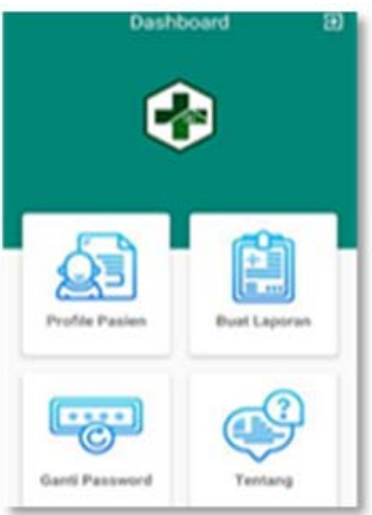

(c)

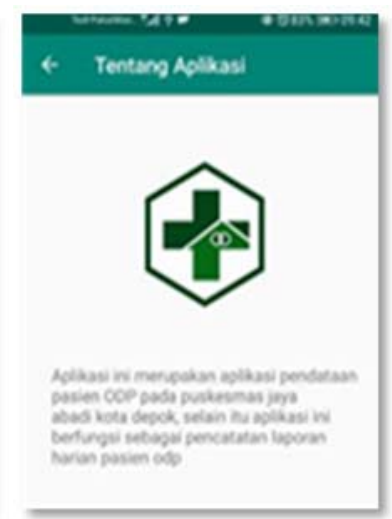

(d)

Gambar 5. (a) Tampilan dashboard aplikasi pada halaman admin/petugas puskesmas;

(b) Tampilan aplikasi monitoring ODP COVID-19 versi Android pada halaman penanggung jawab dan pasien halaman depan; (c) Halaman dashboard; (d) Halaman tentang aplikasi

Tampilan untuk pengisian data laporan harian oleh Penanggung jawab atau pasien ditampilkan pada Gambar 6. Saat button + di-klik, maka akan muncul halaman laporan harian, yang berisi form yang harus diisi untuk menunjukkan kondisi pasien ODP hari itu. Data yang perlu diisi oleh pasien berupa kondisi saat itu, apakah mengalami sesak, apakah mengalami nyeri pada tenggorokan, apakah mengalami batuk, pilek dan diare, serta suhu tubuh yang bersifat opsional, tidak harus diisi karena ada kemungkinan tidak semua pasien memiliki thermometer suhu badan. Setelah mengisi semua kondisi tersebut, pasien dapat meng-klik tombol KIRIM untuk mengirimkan data dan tombol BATAL untuk me-reset form. Nama, tanggal dan waktu pengisian akan secara otomatis tercatat, pasien tidak perlu mengisinya.
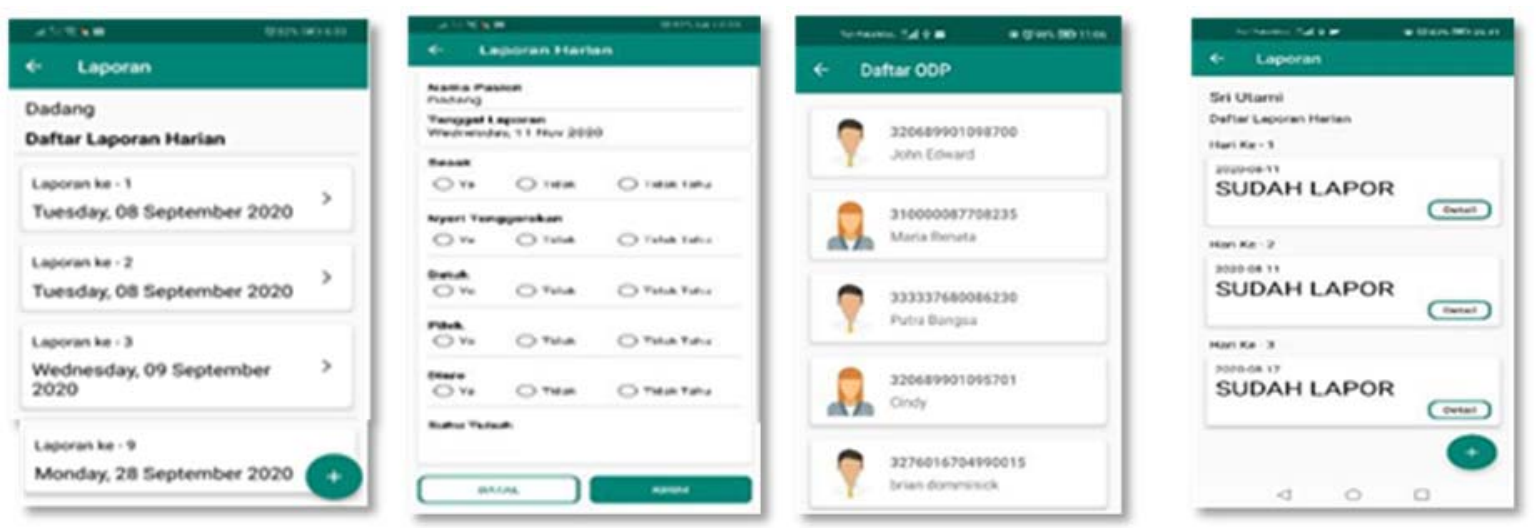

Gambar 6. Tampilan halaman pasien dan penanggung jawab versi Android Gambar 7. Tampilan halaman petugas puskesmas versi Android 
ABDIMAS: Jurnal Pengabdian Masyarakat Universitas Merdeka Malang

Volume 6, No 2, May 2021: 143-152

Gambar 7 menampilkan halaman petugas puskes versi Android untuk memantau Daftar ODP dan melihat halaman Laporan yang menampilkan detail kondisi harian masing-masing ODP. Versi Android untuk petugas puskes diadakan untuk memudahkan petugas memantau dan memastikan progress pasien tanpa harus membuka laptop/komputer. Namun, sesuai fungsi Android untuk memudahkan mobilisasi, tampilan terbatas hanya menampilkan detail pasien dan tidak terdapat dashboard monitoring progress keseluruhan pasien. Petugas puskes dapat memilih salah satu nama pasien, dan akan muncul semua laporan pasien dari hari ke-1 dan seterusnya dan petugas puskesmas dapat melihat detail data yang diisi oleh pasien.

Pengujian aplikasi Monitoring ODP dilakukan 2 jenis pengujian, yaitu: (1) Pengujian black box (Pressman, 2015); dan (2) Pengujian User Acceptance Testing (UAT) (Pandit \& Tahiliani, 2015). Pengujian black box untuk mengevaluasi cara kerja sistem atau aplikasi yang dibuat. Pengujian dilakukan pada dua platform, yaitu web dan Android. Berdasarkan hasil pengujian, diperoleh hasil $100 \%$ semua fitur yang terdapat pada aplikasi web dan Android dapat dijalankan sesuai dengan data masukan dan data keluaran yang diharapkan. Pengujian UAT dilakukan kepada 1 orang admin/petugas puskesmas pada platform web sebagai admin sistem/aplikasi. Penilaian dilakukan secara langsung melalui aplikasi Zoom Meeting. Hasil pengujian UAT oleh admin adalah aplikasi dapat digunakan secara mudah, hanya saja perlu pembiasaan dalam menggunakan fitur dan alur aplikasi. Selain itu, UAT juga dilakukan terhadap platform Android pada pasien ODP sebanyak 45 orang responden dengan 9 pertanyaan terkait parameter desain tampilan, kemudahan dalam penggunaan dan efisiensi aplikasi dengan 5 pilihan jawaban, yaitu Sangat Tidak Setuju (STS), Tidak Setuju (TS), Kurang Setuju (KS), Setuju (S), dan Sangat Setuju (SS), seperti ditampilkan pada Tabel 1.

Tabel 1. Pertanyaan kuesioner UAT

\begin{tabular}{|c|c|c|c|c|c|}
\hline Pertanyaan & STS & TS & KS & $\mathbf{S}$ & SS \\
\hline \multicolumn{6}{|l|}{ Parameter Desain } \\
\hline \multicolumn{6}{|l|}{ Tampilan aplikasi ODP mudah dipahami } \\
\hline \multicolumn{6}{|l|}{ Menu-menu pada aplikasi mudah dipahami } \\
\hline \multicolumn{6}{|c|}{ Penggunaan warna background, logo, gambar/icon dan jenis huruf pada aplikasi sudah tepat } \\
\hline \multicolumn{6}{|l|}{ Parameter Kemudahan Penggunaan } \\
\hline \multicolumn{6}{|l|}{ Pengisian dan update data dapat dilakukan dengan mudah } \\
\hline \multicolumn{6}{|l|}{ Pengisian laporan harian pasien dapat dilakukan dengan mudah } \\
\hline \multicolumn{6}{|l|}{ Pengisian data pasien dan laporan harian dapat dilakukan lebih cepat } \\
\hline \multicolumn{6}{|l|}{ Parameter Efisiensi } \\
\hline \multicolumn{6}{|l|}{ Detail informasi perkembangan pasien ODP lebih cepat diperoleh } \\
\hline \multicolumn{6}{|l|}{ Proses evaluasi perkembangan pasien ODP dapat lebih cepat dilakukan } \\
\hline Aplikasi memudahkan interaksi langsung antara petugas dengan ODP & & & & & \\
\hline
\end{tabular}

Berdasarkan hasil penyebaran kuesioner terhadap tiga penilaian parameter, maka diperoleh data penilaian responden sebagai berikut: (1) Pada parameter desain tampilan, sebesar $88 \%$ responden menjawab Setuju (S) dan Sangat Setuju (SS), sedangkan 12\% menjawab Kurang Setuju (KS) dan Tidak 
Setuju (TS). Hasil pengujian parameter desain tampilan menunjukkan bahwa desain tampilan User Interface (UI) sudah baik, namun masih perlu dilakukan perbaikan pada tampilan warna, background, logo, huruf dan icon; (2) Pada parameter kemudahan penggunaan aplikasi sebesar 92,6\% responden menjawab Setuju (S) dan Sangat Setuju (SS), maka dapat disimpulkan bahwa penggunaan fitur-fitur yang terdapat pada aplikasi sangat mudah digunakan; (3) Sedangkan parameter efisiensi sebesar 93\% responden menjawab Setuju (S) dan Sangat Setuju (SS), sehingga dapat disimpulkan bahwa secara efisiensi aplikasi sangat membantu mempermudah proses pelaporan dan interaksi pasien, maupun keluarga pasien dengan petugas puskesmas.

Mengacu pada 3 parameter yang digunakan pada uji UAT mengenai penerimaan dari sisi user terhadap keberadaan aplikasi, maka dapat dikatakan bahwa aplikasi sudah user friendly/ mudah dipahami dan digunakan, dan membantu proses pemantauan pasien ODP oleh petugas Puskesmas secara efektif dari jarak jauh, tanpa harus bertemu langsung.

\section{SIMPULAN DAN SARAN}

Program Pengabdian Kegiatan Masyarakat (PKM) yang dilakukan oleh PS DIV Teknik Informatika PNJ bekerja sama Puskesmas Depok Jaya Kota Depok, menghasilkan luaran berupa produk Aplikasi Monitoring ODP COVID-19. Aplikasi ini memberikan kemudahan bagi petugas Puskes dalam memonitoring kondisi pasien ODP COVID-19 yang melakukan karantina mandiri. Selain dapat membantu dalam mematuhi protokol kesehatan dalam menjaga jarak untuk meminimalisir penularan virus, aplikasi ini juga lebih efisien dalam hal waktu dan tenaga serta biaya, dimana Petugas Puskes tidak harus berkunjung langsung ke masing-masing rumah pasien ODP, dan sebaliknya, pasien juga tidak harus berkunjung ke Puskes untuk mendapatkan laporan harian pasien. Pengujian Aplikasi Monitoring ODP COVID-19 dilakukan sebelum digunakan. Hasil pengujian menunjukkan bahwa Aplikasi Monitoring ODP COVID-19 secara tampilan, kemudahan penggunaan dan efisiensi sudah baik, namun secara teknis penggunaan, terutama pada sisi pasien, masih terdapat sedikit kesulitan penggunaan karena belum terbiasa dengan fitur-fitur yang ada pada aplikasi.

Mengingat kasus COVID-19 dengan kasus pasien sebagai Orang Tanpa Gejala (OTG) yang juga semakin meningkat dan kasus yang semakin bervariasi, terdapat beberapa saran pada Program PKM berikutnya, terutama pada pengembangan aplikasi ini yaitu: fitur deteksi dini gejala COVID-19, fitur notifikasi bagi admin/petugas Puskesmas jika ada pertanyaan mendesak atau sangat penting yang masuk dari pasien serta ada fitur reminder/pengingat bagi pasien untuk dapat melaporkan data harian mereka.

\section{UCAPAN TERIMA KASIH}

Penulis ucapkan terima kasih kepada Unit Penelitian dan Pengabdian Kepada Masyarakat (UP2M) Politeknik Negeri Jakarata telah membantu dalam pendanaan melalui Hibah Pengabdian Kepada Masyarakat Program Studi sehingga kegiatan pengabdian kepada Masyarakat dapat berjalan lancar. 
ABDIMAS: Jurnal Pengabdian Masyarakat Universitas Merdeka Malang

Volume 6, No 2, May 2021: 143-152

\section{DAFTAR PUSTAKA}

Dima, A. M., \& Maassen, M. A. (2018). From Waterfall to Agile software: Development models in the IT sector, 2006 to 2018. Impacts on company management. Impacts on company management. Journal of International Studies, 11(2), 315-326.

https://doi.org/10.14254/2071-8330.2018/11-2/21

Gogate, U., Marathe, M., Mourya, J., \& Mohan, N. (2017). Android based health monitoring system for cardiac patients. International Research Journal of Engineering and Technology (IRJET), 04(04), 1628-1634.

Kenganal, S. S., \& Rengaprabhu, P. (2016). Real time health care monitoring system using Android mobile. IJAREEIE: International Journal of Advanced Research in Electrical, Electronics and Instrumentation Engineering, 5(5), 4050-4057. https://doi.org/10.15662/IJAREEIE.2016.0505107

Masi, E., Cantone, G., Mastrofini, M., Calavaro, G., \& Subiaco, P. (2012). Mobile apps development: A framework for technology decision making. International Conference on Mobile Computing, Applications, and Services MobiCASE 2012: Mobile Computing, Applications, and Services, 6479. https://doi.org/10.1007/978-3-642-36632-1_4

Pandit, P., \& Tahiliani, S. (2015). AgileUAT: A framework for user acceptance testing based on user stories and acceptance criteria. International Journal of Computer Applications, 120(10), 16-21. https://doi.org/10.5120/21262-3533

Patel, N., \& Kher, R. (2016). Android based application development for health monitoring. International Journal of Advanced Computing and Electronics Technology (IJACET), 3(2), 53-56.

Pemerintah RI. Daftar Protokol. Diakses pada 17 April 2020 dari:

https://www.COVID19.go.id/daftar-protokol/

Pemerintah Kota Depok. Pembentukan Kampung Siaga COVID-19 di Depok Capai 97,6 Persen. Diakses pada 20 April 2020 dari: https://berita.depok.go.id/pemerintahan/pembentukan-kampungsiaga-COVID-19-di-depok-capai-976-persen-2392

Pemerintah Kota Depok. pemerintahan. Diakses pada 20 April 2020 dari: https://berita.depok.go.id/ pemerintahan/tanggulangi-wabah-corona-dinkes-maksimalkan-peran-puskesmas-2375

Pressman, R. S. (2015). Software Engineering: A Practitioner's Approach. Eight Edition. New York: McGraw-Hill Education.

Republika. Berita. Diakses pada 23 April 2020 dari: https://republika.co.id/berita/q8isvj380/atasiCOVID19-dinkes-depok-maksimalkan-peran-puskesmas 